\title{
Robotic Exoskeleton for Rehabilitation of the Upper Limb
}

\author{
Boris Jobbágy ${ }^{1, *}$, Dušan Šimšík ${ }^{1}$, Jiří Marek $^{2}$, Ján Karchňák ${ }^{1}$, Daniela Onofrejová3 \\ ${ }^{1}$ Department of Automation, Control and Human Machine Interaction, Faculty of Mechanical Engineering, Technical University of \\ Košice, Slovak Republic \\ ${ }^{2}$ Department of Robotics, Faculty of Mechanical Engineering, VŠB - Technical University of Ostrava, Czech Republic \\ ${ }^{3}$ Department of Industrial Engineering and Management, Faculty of Mechanical Engineering, Technical University of Košice, \\ Slovak Republic \\ *Corresponding author: boris.jobbagy@tuke.sk
}

Received October 22, 2014; Revised November 05, 2014; Accepted November 18, 2014

\begin{abstract}
This paper deals with robotic exoskeletons and their using in rehabilitation of the upper limbs. First part describes application of robotic devices in rehabilitation. In the second part there is described an architecture of rehabilitation robotic system and its main subsystems. Third part of the proposed paper is dedicated to robotic exoskeletons. This section deals with internal and external force action in exoskeletons. In the last part of the paper, there is shown design of robotic exoskeleton for the upper limb.
\end{abstract}

Keywords: exoskeleton, rehabilitation, upper limb, pneumatic artificial muscle

Cite This Article: Boris Jobbágy, Dušan Šimšík, Jiří Marek, Ján Karchňák, and Daniela Onofrejová, "Robotic Exoskeleton for Rehabilitation of the Upper Limb." American Journal of Mechanical Engineering, vol. 2, no. 7 (2014): 299-302. doi: 10.12691/ajme-2-7-27.

\section{Introduction}

Robotic technology is currently becoming one of the essential elements of a comprehensive restructuring and automation in the manufacturing and non-manufacturing sector. In the future, there is expectation of significant percentage rise of elderly people (65+), about $1 / 3$ of the population. This fact makes an opportunity for the deployment of robotic devices, especially in rehabilitation of the upper limbs. Such applications have high demands on development of associated devices. Current robotics uses for these cases principles of biomechanics and biomechanisms. For designing these robotic devices, it is important to use knowledge about anatomy of the upper limb in biomechanical principles of proposed rehabilitation robot [1,2].

\section{Architecture of Robot-assisted Rehabilitation of the upper Limb}

The main functions of robot-assisted rehabilitation are:

- measurement and evaluation of patient's physical condition for specifying diagnosis and selection of suitable therapy

- controlled manipulation of the treated motional segment to improve its motional abilities

The basic system function of these diagnostic and mechano-therapeutic systems is:
- controlling movement in the joint of the robotic arm (adjustable range of motion, adjustable load, speed and acceleration, controlled trajectory of the arm with more than two degrees of freedom)

- collecting, processing and analysis of measured data (real-time measurement, monitoring, statistical and graphical analysis)

- effectiveness of the rehabilitation procedures

- reliability and safety

- motivation and comfort of the patient

Architecture of rehabilitation robotic systems (RRS) has its own specifications which results from the requirements for anthropometric, biomechanical and medical aspects. Architecture of RRS can be described by arranged structure, Figure 1, [1,3].

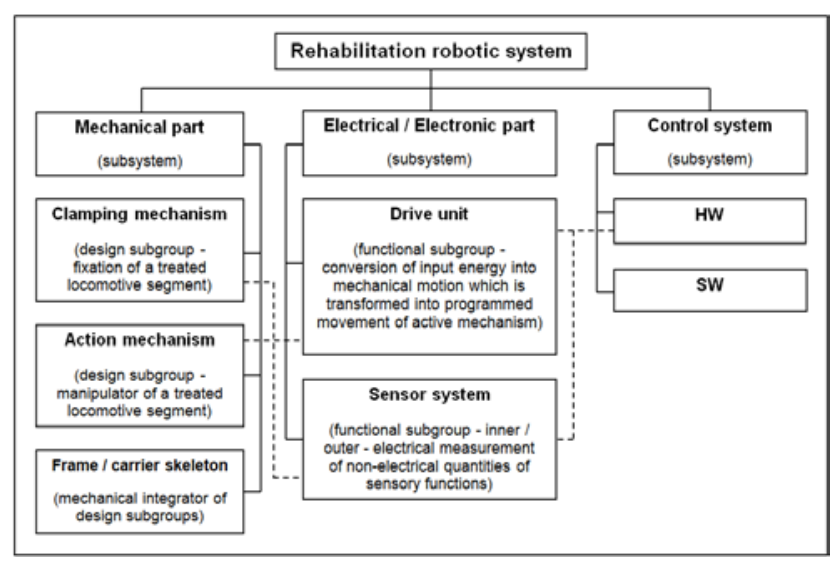

Figure 1. Architecture of rehabilitation robotic system [1] 


\section{Exoskeletons in Rehabilitation Robotics}

Exoskeleton is defined as active robotic device with anthropomorphic kinematics. It is worn by user, adheres to his body and cooperates with user's movements or user cooperates with movements of the exoskeleton [4]. Exoskeletons were firstly used in industrial but mostly in military applications. For such purposes, exoskeletons for amplification of physical abilities of the user were developed. Rehabilitation is another area of their utilization.

In exoskeleton, there is transport of energy between human and robot. Mutual interaction of mechanical construction and human limb can be provided by applying inner or outer force action. The determining whether the force is inner or outer depends on an application. Conception of outer force action deals with empowering exoskeletons, Figure 2, and their aim is to increase user's force. This exoskeleton has to be able to resist outer forces, which are acting on it from environment so that forces have to be grounded. That means the fact that most of force applied is absorbed by mechanical construction and only small, negligible force is transmitted to the operator. The only force interaction between operator and robot is when user acts on the exoskeleton with the aim to control it. On the other hand, orthotic/therapeutic exoskeletons or exoskeletons for functional compensation of physical disability of limbs, Figure 2, use the principle of inner force interaction. Force is transferred from robot onto human limbs. Orthotic/therapeutic exoskeletons are implemented when limbs are weakened or functionally limited. This kind of assistive technology is intended to strengthen, restore or, in some cases, replace movement abilities of limbs. These exoskeletons should be able to complement or replace motoric function of human's muscle-bone system. In this case, inner force action is not grounded - exoskeleton acts by force on limbs and forces them to move $[5,6]$.
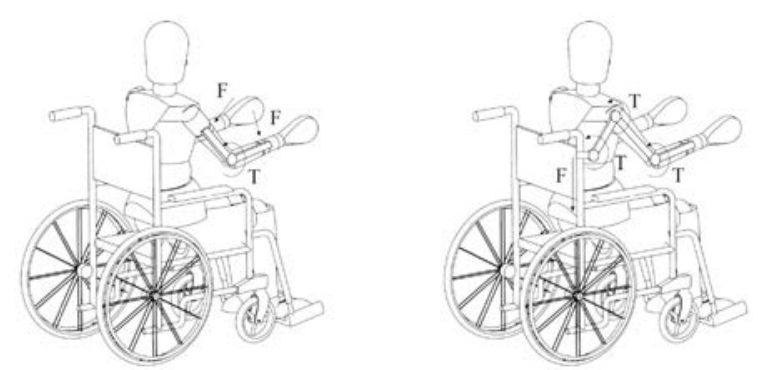

Figure 2. Internal (on the left) and external (on the right) force action in exoskeleton $[5,6]$

Special aspect of exoskeletons is their kinematic chain that has to be compatible with kinematic chain of human limb. In other words, joint's axes of the exoskeleton have to be identical to joint's axes of human. This kinematic compatibility is the key aspect for reaching ergonomic interface HUMAN-ROBOT. Exoskeleton must not compromise or limit user in performing of natural moves. Kinematic compliance has meaning in exoskeletons which work on principle of inner force action. Typical demonstration of kinematic incompatibility is creation of unwanted force interactions on places and areas where both systems are connected to each other. However, avoiding of such problem is very difficult $[5,6]$.

\section{Design of an Exoskeleton for the Upper Limb}

Conception of the designed rehabilitation robot is based on the structure of the rehabilitation robotic system which is shown on Figure 1. The main parts of the mechanical subsystem are clamping and action mechanisms. Clamping mechanism has to fix treated motional segment (upper limb) and it has to achieve stability of this segment during rehabilitation process. It must not block circulation of the blood and it has to provide maximum comfort to treated segment. Action mechanism is a robotic arm which imitates motions of the treated motional segment.

Kinematic analysis of the upper limb is very important for the design of proposed robotic arm. Mobility of the upper limb consists of movements in three functional areas - movements in shoulder, elbow and wrist joint. On the Figure 3, there is modified kinematic model of the upper limb.

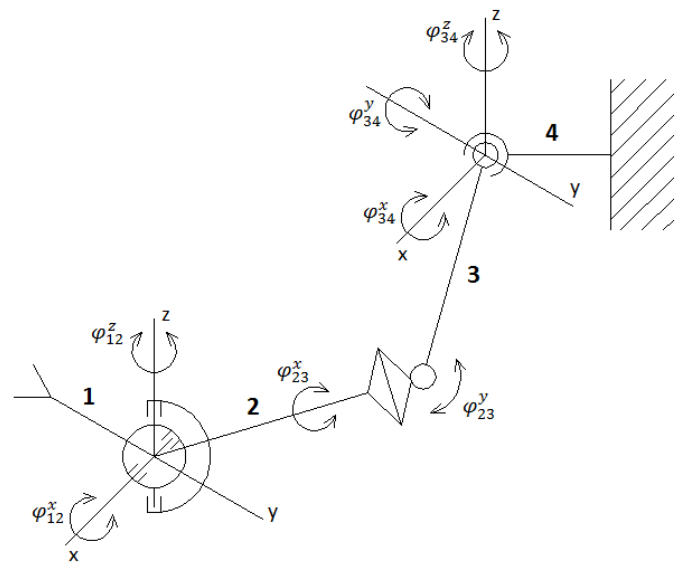

Figure 3. Modified kinematic model of the upper limb [7]

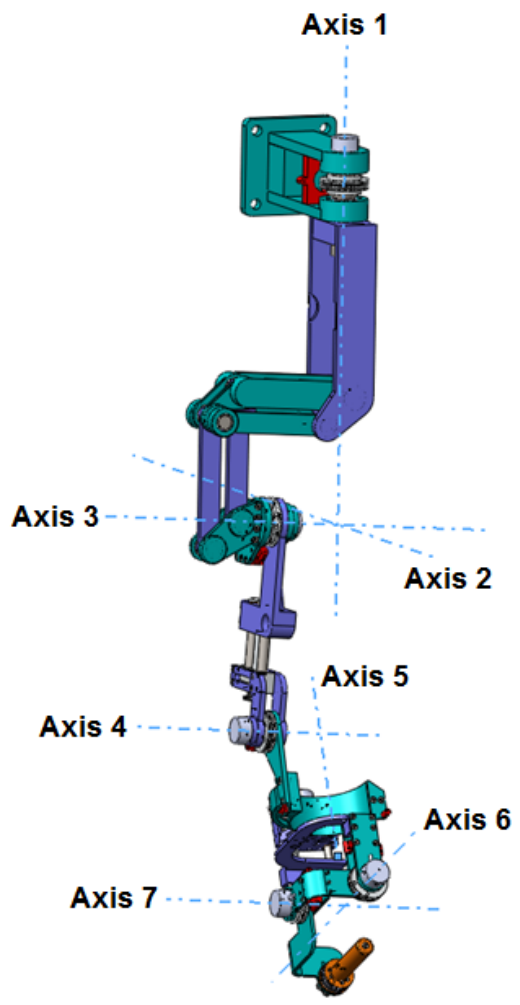

Figure 4. Robotic exoskeleton for upper limb [1] 
According to the requirements of the rehabilitation process and on the basis of the kinematic analysis of the upper limb, there was designed robotic exoskeletal system for upper limb and its scheme is on Figure 4.

Exoskeleton has seven degrees of freedom (DOF). Three DOF are in the shoulder joint, another two DOF are in the elbow joint and two DOF are in the wrist joint. Seven DOF is needed for the full mobility of the upper limb. Axes in shoulder joint are arranged to intersect in one point as it is in the shoulder joint of the upper limb. There is achieved kinematic compatibility in shoulder joint which is very important to achieve kinematic compatibility in whole mechanism.

Every joint (except of joint in axes 3) is equipped with incremental rotary encoder Heidenhain ERO 1400, Figure 5, for purpose to measure angle of rotation. Encoder is without integral bearing and it's self-centring.
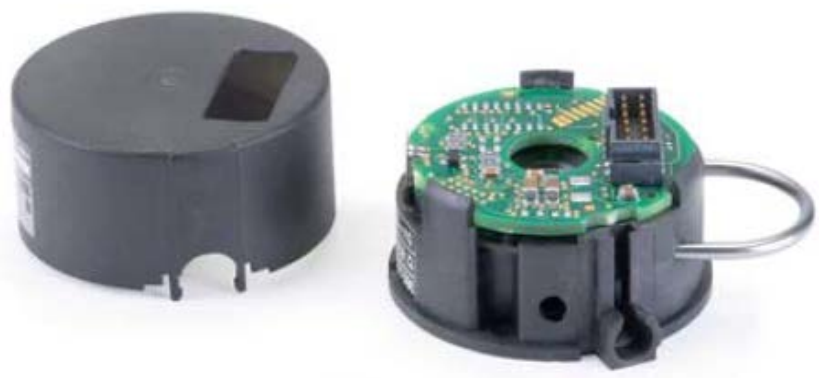

Figure 5. Incremental rotary encoder (Heidenhain ERO 1400)[8]

Joint in axes 3 is equipped with absolute rotary encoder Heidenhain EBI 1135, which is also without integral bearing, Figure 6.

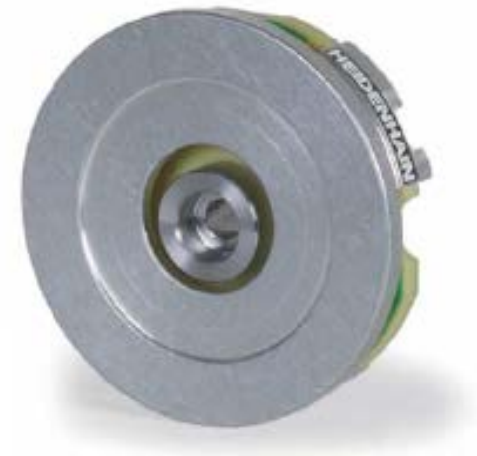

Figure 6. Absolute rotary encoder (Heidenhain EBI 1135) [8]

The arm is adjustable in length for different sizes of the upper limb. It is adjustable in three segments: wrist, forearm and upper arm segment. Also carrier frame is adjustable in length in three axes which are perpendicular to each other. The carrier frame works as manipulator with three translational motion units, Figure 7. During rehabilitation process, patient is sitting on a chair which is fixed to the ground, or patient can also sit on a wheelchair.

Each joint of the arm is driven by couple of pneumatic artificial muscles (PAM) which are arranged in antagonistic connection, Figure 8. Artificial muscle can only reduce its length and that is reason for implementation of another muscle for the regression movement in the joint. Muscles are placed outside of the arm, they are placed in carrier frame, as shown in Figure 7. Transmission of motion between actuators - PAM and joints of the robotic device is done by cables which are held in bowdens. Cables are connected to pulleys in the joints of the robotic arm.

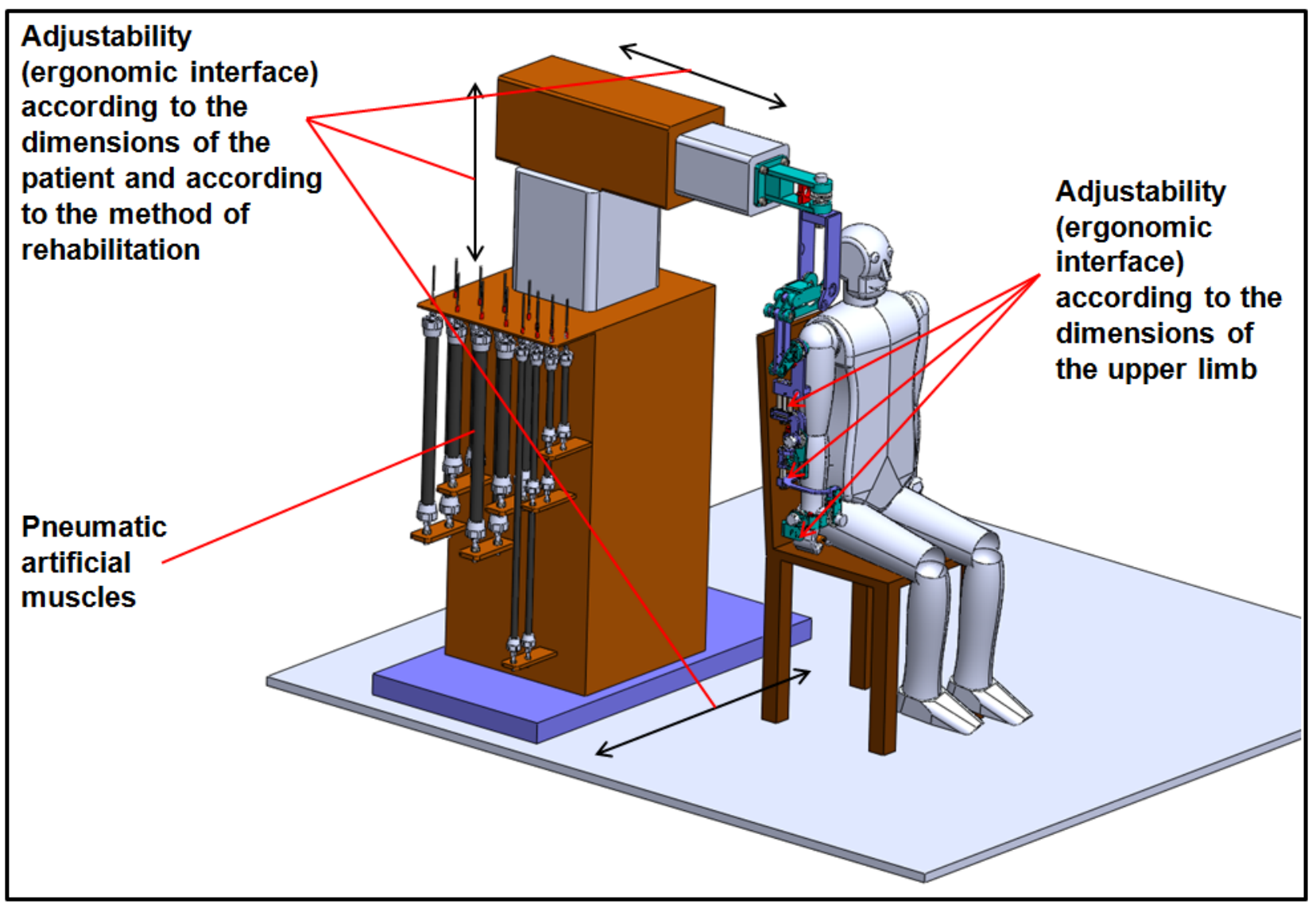

Figure 7. The layout of the entire rehabilitation robotic system (arm + carrier frame) 

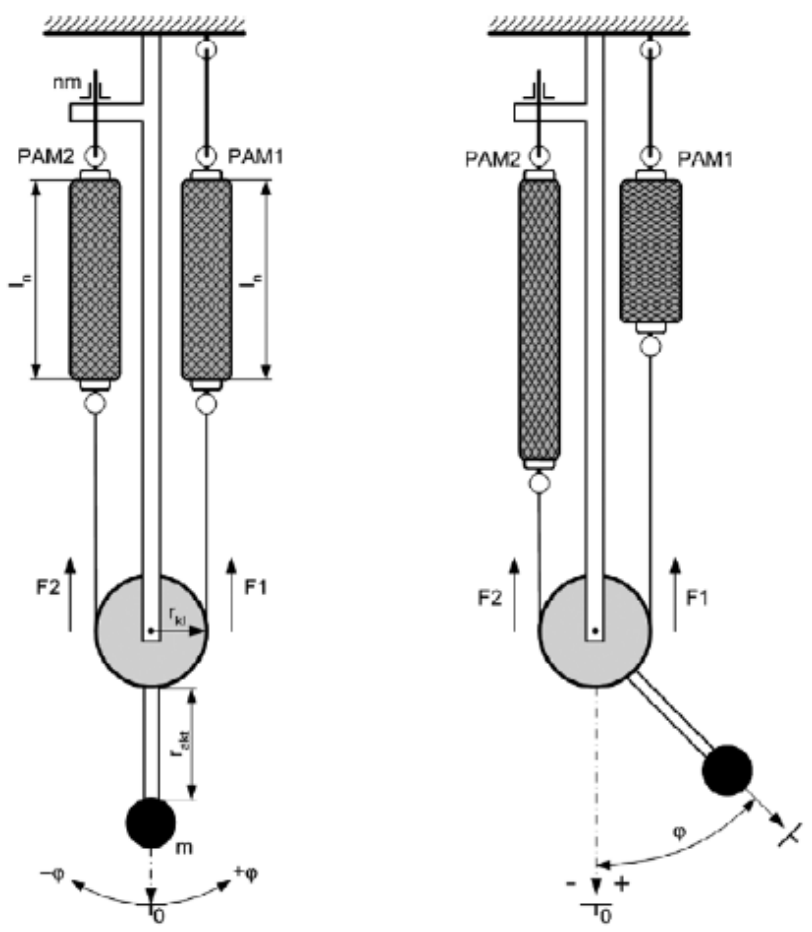

Figure 8. Pneumatic artificial muscles in antagonistic connection [9]

\section{Conclusion}

Proposed article describes using robotic devices in rehabilitation process. This would increase number of rehabilitated patients per a period of time. There is also described an architecture of the robot-assisted rehabilitation of the upper limb. Next part of the paper deals with robotic exoskeletons and with their distribution. Using an exoskeleton, we can achieve bigger range of motions. The upper limb is connected with an exoskeleton in several points. Our design of rehabilitation robotic device is also based on a principle of an exoskeletal system. In our approach, as actuators are used pneumatic artificial muscles, which are in antagonistic connection.
This work has been supported by the Slovak Grant Agency VEGA contract Nb. 1/0911/14 "Implementation of wireless technologies into the design of new products and services to protect human health", and structural funds of EÚ, program Research and development, 2.2 Transfer of knowledge and technology from research to praxis: "Research and development of intelligent nonconventional actuators using artificial muscles”. ITMS code: 26220220103.

\section{References}

[1] Jobbágy, B.: Vývoj robotických zariadení s pneumatickými svalmi pre rehabilitáciu končatín - Doktorandská dizertačná práca. Košice, 2014.

[2] Šimšík, D. a kol.: Rehabilitačné inžinierstvo. Edícia ved. a odb. literatúry - SjF TU v Košiciach, C-press, Košice 2011. ISBN 97880-553-0559-2.

[3] Smrček, J.,Tuleja, P., Friga, P.: Aplikácia robotických systémov v zdravotníctve. In: Strojárstvo / Strojírenství, roč. XII., č. 5/2008, MEDIA/ST Žilina, Žilina 2008, s. 136-137. - ISSN 1335-2938.

[4] DOLLAR, A. M. - HERR, H.: Lower Extremity Exoskeletons and Active Orthoses: Challenges and State-of-the-Art. In: IEEE TRANSACTIONS ON ROBOTICS, VOL. 24, NO. 1, FEBRUARY 2008. [online]. Dostupné na: $<$ http://www.eng.yale.edu/grablab/pubs/dollar_tro_exos.pdf>

[5] ROCON, E. - PONS, J. L.: Exoskeletons in Rehabilitation Robotics. Tremor Suppression. Edited by Bruno Siciliano, Oussama Khatib, Frans Groen. Springer - Verlag Berlin Heidelberg, 2011. ISBN 978-3-642-17658-6.

[6] Jobbágy, B., Šimšík, D., Smrček, J., Veselíny, M.: Robotické rehabilitačné zariadenia pre rehabilitáciu horných končatín. In: Trendy v biomedicínskom inžinierstve 2013, Vysoké Tatry, Podbanské, Slovak republik, July 3-5, 2013, - Košice: TU, s. 72 75, ISBN 978-80-8086-208-4.

[7] NOVÁK-MARCINČIN, J. - SMRČEK, J.: Biorobotika-teória, princípy, aplikácia v technickej praxi. Academic Press, elfa Košice, Košice 1998.

[8] HEIDENHAIN. Measurement and Control Technology for Demanding Positioning Tasks. [online]. Dostupné na: $<$ http://www.heidenhain.com/en_US/home/>

[9] Pitel', J., Balara, M.: Pneumatický umelý sval - perspektívny prvok mechatroniky. In: AT\&P journal 4/2009, s. 59 -62. [online]. Dostupné <http://www.atpjournal.sk/buxus/docs/casopisy/atp_2009/pdf/onli ne84.pdf $>$

\section{Acknowledgement}

